\title{
ГОСУДАРСТВЕННЫЕ РЕГИОНАЛЬНЫЕ СРЕДНЕСРОЧНЫЕ ПРОГРАММЫ РАЗВИТИЯ - ОСНОВА ФОРМИРОВАНИЯ ГОСУДАРСТВЕННОГО РЕГИОНАЛЬНОГО РЫНКА ТОВАРОВ, РАБОТ, УСЛУГ
}

\author{
(c) 2019 Старовойтова Дарья Павловна \\ аспирант \\ Институт региональных экономических исследований, Россия, Москва \\ E-mail: Ipranran@mail.ru \\ (c) 2019 Филиппов Антон Павлович \\ кандидат экономических наук, ведущий научный сотрудник \\ Институт региональных экономических исследований, Россия, Москва \\ E-mail: Ipranran@mail.ru
}

В статье показана роль среднесрочного программирования в субъекте Федерации и его влияния на формирование регионального рынка товаров, работ, услуг для общественных нужд.

Ключевые слова: общественные услуги, ресурсное обеспечение, государственное регулирование, государственные программы развития.

Одним из стратегических источников интенсификации производства общественных услуг является способность производителя обеспечить формирование среды для структурирования и трансформации ресурсов в воспроизводственном процессе. При этом понятие «общественная услуга» имеет широкие границы, в рамках которых такая услуга идентифицируется с разных позиций.

Специалисты института Экономики РАН характеризуют общественные услуги как имеющие приоритетное (базовое) значение для общества, государства и потребителя [1].

Теория и практика показывают, насколько качественно выстраиваются связи производителя с поставщиками ресурсов, и осуществляется межфункциональная организация в учреждении, связанная с закупочной деятельностью и ресурсным обеспечением, настолько будет определена эффективность общественной услуги.

Федеральный закон № 44-Ф3 открыл новый этап на пути осуществления экономической реформы, создания подлинно рыночных механизмов государственного и частного предпринимательства, перехода к государственному контракту и государственному рынку товаров, работ и услуг.

Опыт экономики индустриально развитых стран показывает, что качественно новый характер их экономики основан на сочетании таких принципов рыночного хозяйства как конкуренция, свобода экономического выбора, возмож-

ность саморегулирования, так и регулирующей роли государства в экономическом развитии и решении социальных проблем.

Объективно существует ряд таких условий, определяющих повышение роли государства в современных социально-экономических процессах как:

- изменения структуры хозяйственной деятельности государства, вызванные процессами глобализации;

- превращение государства в мощный хозяйствующий субъект;

- невозможность рынка самостоятельно решать социальные проблемы;

- необходимость разработки и реализации долгосрочной политики социально-экономического развития.

Задачи повышения качества государственных услуг требуют решения вопросов модернизации системы государственного управления городом на основе новых экономических механизмов и управленческих технологий.

В целях обеспечения конкурентоспособности г. Москвы как экономического и культурного центра, одним из основных объектов модернизации стал государственный сектор экономики. Приоритетами региональной экономической политики должны стать:

- повышение уровня обслуживания, качества и доступности государственных и социально значимых услуг, оказываемых за счет средств бюджета г. Москвы, оптимизация контрольных 
функций;

- повышение качества планирования, ответственности за выполнение планов;

- повышение качества управления бюджетными средствами;

- повышение качества межведомственных действий.

Достижению данных целей призвана служить формируемая система взаимоувязанных плановых документов с прозрачным механизмом контроля их взаимосвязи и реализации.

В систему региональных плановых документов входят:

- стратегия - определяющая целевые ориентиры социально-экономического развития региона (субъекта Федерации) на длительный период до 15 лет;

- генеральный план - определяющий положения о территориальном планировании города, включающий в себя карты и схемы территориального планирования;

- отраслевые схемы - разрабатываемые как дополнение к схемам территориального планирования города, предусматривающие размещение объектов инфраструктуры в разрезе отраслей;

- государственные среднесрочные программы (на 5 лет), включающие систему действий (взаимоувязанных по задачам и срокам осуществления) Правительства Москвы (регулятивные и финансовые). С 2012 г. в г. Москве разрабатываются государственные среднесрочные отраслевые программы развития по приоритетным отраслям городского хозяйства. Государственные городские программы стали механизмом политики города, фиксируя связь «мероприятие - результат - ответственный за результат». Государственные городские программы развития стали как основой внедрения программно-целевого метода управления бюджетными средствам, удельный вес расходной части бюджета, формируемого в рамках программ, традиционно с 2012 г. составляет не менее 90\% против 13,5\% в 2011 г.

Инициаторами разработки городских государственных программ развития отраслей городского хозяйства на среднесрочный период 2012-2016 гг. стали Правительство Москвы и отраслевые департаменты городской администрации, всего разрабатывалось 17 государственных программ по таким приоритетным отраслям как градостроительная политика, здравоохране- ние, образование, социальная защита населения, культура и т.д.

Отбор проблем для программной разработки осуществлялся на основе существующего положения дел и степени влияния на достижение важнейших целей.

Так, структура и содержание государственной программы г. Москвы на среднесрочный период 2012-2016 гг. «Развитие индустрии отдыха и туризма» составляла 5 подпрограмм, 28 мероприятий, 5 ответственных исполнителей, 11 соисполнителей.

Актуализированная по результатам 20122014 гг. до 2018 г. программа в новой редакции составляет 3 подпрограммы, 21 мероприятие. Изменены и объемы бюджетного финансирования с 81,28 млрд.руб. на 2012-2016 г. до 174,65 млрд.руб. на 2012-2018 гг., из них на 43,37 млрд. руб. из-за изменения структуры программы и 50 млрд.руб. из-за увеличения срока реализации на 2 года.

Финансирование программы из бюджета г. Москвы с 2012 г. ежегодно составляет более 22 млрд.руб., в т.ч. на 2018 г.- 22,405 млрд.руб. Финансовое обеспечение подпрограммы «Индустрия отдыха и туризма на территории парков культуры и отдыха, музеев-заповедников и музеев-усадеб на 2012-2018 гг.» составляет 60,06 млрд.руб.

В результате реализации Государственной программы планировалось достижение следующих результатов в социальной сфере:

- увеличение количества посетителей парков культуры и отдыха в 2,8 раза;

- увеличение количества посетителей, занимающихся в культурно-досуговых формированиях и спортивных секциях парков культуры и отдыха в 80 раз от уровня 2010 г.;

- расширение спектра культурно-массовых, спортивно-оздоровительных, эколого-просветительских мероприятий, обеспечение доступа людей с ограниченными возможностями во все 100\% рекреационных территорий, комплексов и объектов [2].

По состоянию на 2012 г. большинство парков культуры и отдыха имели моральный и физический износ около $80 \%$, а на ряде парковых территорий коммуникации отсутствовали. Аварийными были признаны объекты культурного наследия и территории усадебных комплексов Останкино, Кусково, Кузьминки.

В результате реализации основных меро- 
приятий подпрограммы «Индустрия отдыха и туризма на территориях парков культуры и отдыха, музеев-заповедников и музеев-усадеб»:

- освобождение от уплаты налога на имущество бюджетных и казенных учреждений города;

- благоустройство территорий;

- расширен ряд культурных, спортивных и просветительских мероприятий;

- ремонтные работы музеев, усадеб и заповедников;

- ремонтные работы парков культуры и отдыха.

Объем финансовых ресурсов, необходимый для реализации подпрограммы на 2012-2018 гг., составил 60 056,675 млн.руб., в т.ч. 51317,875 млн. руб. за счет средств бюджета города, уточняемый при составлении и принятии закона г. Москвы о бюджете города на соответствующий финансовый год и плановый период, а также 8738,799 млн.руб. средств государственных учреждений города от приносящей доход деятельности.

Рост объемов финансовых ресурсов, подлежащих распределению для реализации госпрограмм развития, выдвигает вопросы организации контрактной системы в сфере закупок товаров, работ и услуг на одно из приоритетных мест. А госпрограммы становятся основой формирования государственного рынка товаров, работ, услуг.

Опыт реализации госпрограммы 20122018 гг. показывает ее экономическую, социальную и экологическую эффективность. Формирование экономических механизмов, создающих привлекательные условия для бизнеса, способствуют росту инвестиций.

Эффективность разработки и реализации программы характеризуется следующими показателями по отношению к 2010 г.:

- увеличилось количество посетителей парков в 2,8 раза;

- увеличилось количество, занимающихся в досуговых и спортивных секциях в 8,0 раза;

- увеличился объем услуг посетителям парков в 4,6 раза, посетителям заповедников и усадеб - в 4,4 раза;

- увеличилось число иностранных туристов в 2,9 раза;
- увеличилась доля доходов парков по отношению к объему финансирования на текущее содержание парков до $52 \%$.

Как видим, практика внедрения программно-целевого метода управления путем формирования системы взаимоувязанных плановых документов (стратегия, генплан, среднесрочные государственные программы развития приоритетных отраслей городского хозяйства, бюджеты на текущий год и плановый период) показали свою жизнеспособность и эффективность.

Новая среднесрочная программа развития паркового хозяйства столицы на 2019-2023 гг., являясь следующим логическим шагом пространственного развития г. Москвы, полнее обеспечивает взаимоувязку стратегических, среднесрочных и текущих плановых документов регионального уровня.

В свою очередь, требует продолжения работы над повышением эффективности функционирования системы государственных закупок, вносящих существенный вклад в развитие отечественной экономики путем перераспределения значительных финансовых ресурсов бюджетной системы среди хозяйствующих субъектов, формирования государственного рынка товаров, работ и услуг.

Парламентские слушания в Совете Федерации, прошедшие 24 октября 2019 г. по «Вопросам совершенствования законодательства Российской Федерации о контрактной системе в сфере закупок товаров, работ, услуг для обеспечения государственных и муниципальных нужд», станут новым этапом модернизации отечественной контрактной системы. При этом реализация курса на децентрализацию и муниципализацию управления г. Москвы путем формирования первичного финансово-экономического дееспособного районного звена, по мнению специалистов, будет способствовать как более полному внедрению Федерального закона № 172-Ф3 «О стратегическом планировании в Российской Федерации», включившего муниципальные образования в систему стратегического планирования, так и более полному учету мнения и нужд жителей при формировании программ пространственного развития столицы $[3,4,5]$.

\section{Библиографический список}

1. Управление закупками в инновационной экономике: вопросы теории и практики / Под. ред.д.э.н. Смотрицкой И.И.-М. Институт экономики РАН. 2015.

2. Государственная программа города Москвы «Развитие туризма и отдыха на 2012-2018 гг.». 
3. Федеральный закон от 28.06. 2014 № 172-Ф3 «О стратегическом планировании в Российской Федерации».

4. Бурак П.И. «Научно-методические аспекты реализации Федерального закона «О стратегическом планировании в Российской Федерации на региональном уровне». М. Вестник РАЕН 2015/6. Т.15. C.4.

5. Филиппов А.П. «Об оптимальном управлении современным мегаполисом // Самоуправление. М. 2016 № 7-8. 